\title{
THE DECREASING EFFORTS ON 45 BUILDING IN PARAHYANGAN CATHOLIC UNIVERSITY BANDUNG ACCORDING TO GREENSHIP NB1.2 CRITERIA
}

\author{
${ }^{1}$ Alexander Gunawan. ${ }^{2}$ Dr. Ir. Yasmin Suriansyah, M.S.P. \\ ${ }^{1}$ Student in the Bachelor's (S-1) Study Program in Architecture \\ at Parahyangan Catholic University \\ ${ }^{2}$ Senior lecturer in the Bachelor's (S-1) Study Program in Architecture \\ at Parahyangan Catholic University
}

\begin{abstract}
Every projects should be sustainable and enviromentally friendly. There are many organization that promote a sustainable construction projects, one of them is Green Building Council Indonesia (GBCI), with its GREENSHIP rating tools.

Building45 is one of the latest buildings in UNPAR university complex. After doing pre-research based on Building 45 condition, the building doesn't meet a few green building criteria based on GREENSHIP New Building 1.2. One of it is the OTTV value, Building 45 has a high OTTV value. A research to optimize the OTTV value should be conducted.

The research was conducted with simulation method to optimize the OTTV value but didn't interfere the other green building aspect such as its natural lighting. The variable of the optimization is WWR value, shading element, and the transparent material of the building.

The most effective variable to reduce OTTV value is by WWR arrangement.The OTTV value can be optimized to reach $28.62 \mathrm{~W} / \mathrm{m}^{2}$, and $39.2 \%$ of the first floor and $30.3 \%$ of the second floor area still have natural lighting iluminousity of more than 300 lux. The OTTV optimization can increase the green building rating of Building 45 by 5 points based on GREENSHIP NB 1.2.
\end{abstract}

Key Words: Optimalization, OTTV, GREENSHIP NB 1.2, WWR, natural lighting

\section{UPAYA PENURUNAN NILAI OTTV PADA GEDUNG 45 UNIVERSITAS KATOLIK PARAHYANGAN BANDUNG SESUAI KRITERIA GREENSHIP NB1.2}

\author{
${ }^{1}$ Alexander Gunawan. ${ }^{2}$ Dr. Ir. Yasmin Suriansyah, M.S.P. \\ 1 Mahasiswa S1 Program Studi Arsitektur Universitas Katolik Parahyangan. \\ 2 Dosen Pembimbing S1 Program Studi Arsitektur Universitas Katolik Parahyangan
}

\begin{abstract}
Abstrak- Setiap proyek haruslah berkelanjutan dan ramah lingkungan. Upaya untuk mendukung pembangunan yang berkelanjutan, salah satunya dilakukan oleh Green Building Council Indonesia yang menerbitkan rating tools GREENSHIP.

Gedung 45 merupakan salah satu bangunan yang baru berdiri, tetapi setelah dilakukan penilaian terkait dengan bangunan hijau, gedung ini masih belum memenuhi kriteria bangunan hijau. Salah satu kriteria yang belum terpenuhi adalah nilai OTTV. Oleh karena itu diperlukan penelitian terkait dengan optimalisasi nilai OTTV pada Gedung 45.

Penelitian dilakukan menggunakan metode simulasi untuk mengetahui nilai OTTV yang optimal tetapi tidak mengganggu kriteria penilaian bangunan hijau yang lain. Variabel optimalisasi yaitu nilai WWR, material bukaan, dan elemen peneduh Gedung 45.

Variabel yang paling efektif untuk menurunkan nilai OTTV adalah WWR. Hasil simulasi menunjukan bahwa nilai OTTV Gedung 45 dapat di optimalisasi hingga mencapai tingkat $28.62 \mathrm{~W} / \mathrm{m} 2$ dan luas lantai dengan iluminasi pencahayaan alami lebih dari 300 lux sebesar $39.2 \%$ pada lantai 1 dan $30.3 \%$ pada lantai 1 A.
\end{abstract}

\footnotetext{
${ }^{1}$ Corresponding Author: alexander_gunawan@hotmail.com
} 
Optimalisasi nilai OTTV tersebut dapat meningkatkan nilai Gedung 45 sebesar 5 poin berdasarkan standard GREENSHIP NB 1.2.

Kata Kunci: Optimalisasi, OTTV, GREENSHIP NB 1.2, WWR, pencahayaan alami

\section{PENDAHULUAN}

Dewasa ini, populasi dunia terus meningkat. Peningkatan populasi dunia akan memicu peningkatan penggunaan sumber daya alam untuk menciptakan lingkungan binaan yang baru dan akan memberikan dampak ekologis. Lingkungan binaan merupakan segala sesuatu yang merupakan hasil buatan manusia dalam usahanya untuk mencapai tujuan sehingga dapat memberikan pengaruh terhadap konteks lingkungan tersebut. Bangunan merupakan salah satu komponen lingkungan binaan yang tentunya memiliki jejak ekologis yang signifikan. Oleh karena itu, diperlukan desain yang berkelanjutan.

Upaya yang dilakukan untuk mendukung pembangunan yang berkelanjutan yaitu dengan membentuk Green Building Council Indonesia (GBCI) yang menerbitkan rating tools untuk menilai penerapan konsep bangunan hijau.

Konsep Green Campus yang salah satunya mencakup penerapan konsep bangunan hijau sudah mulai diterapkan di UNPAR. Gedung 45 merupakan bangunan yang baru berdiri di lingkungan UNPAR. Meskipun memiliki konsep Green Campus, namun masih terdapat berbagai aspek bangunan hijau yang belum terpenuhi pada Gedung 45, diantaranya keperluan ruang untuk pengolahan air hujan, penurunan nilai OTTV, perbaikan sistem M/E, perbaikan tata letak ruang, perbaikan interior ruangan terkait dengan elemen akustik bangunan, dan aspek yang tidak dapat diperbaiki karena merupakan aspek bawaan dari tapak.

Aspek yang terkait dengan penurunan nilai OTTV merupakan pokok penilaian EEC P2 dan EEC 1C-1 berdasarkan GREENSHIP NB 1.2. Aspek ini memiliki bobot penilaian yang besar dan merupakan elemen prasyarat, sehingga memiliki urgensi terbesar untuk diteliti. Upaya yang dapat dilakukan untuk menurunkan nilai OTTV yaitu dengan mengubah material, optimalisasi nilai WWR, dan memperpanjang elemen peneduh bangunan. Penelitian ini bertujuan untuk menjawab pertanyaan penelitian mengenai aspek yang paling optimal untuk menurunkan nilai OTTV di antara variabel WWR, elemen peneduh, dan material bangunan serta mendefinisikan konfigurasi fasad dengan nilai OTTV yang paling optimal. Perubahan nilai OTTV diharapkan tidak mengganggu aspek penilaian yang lain seperti aspek pencahayaan alami pada bangunan.

\section{KAJIAN TEORI}

\section{OTTV}

OTTV (Overall Thermal Transfer Value) adalah nilai perolehan panas akibat radiasi matahari yang melewati setiap meter persegi luas selubung bangunan. OTTV dapat digunakan untuk mengetahui performa selubung bangunan dalam mengkondisikan bangunan dari ruang luar yang lebih panas, sehingga selubung bangunan tidak hanya bagus secara estetika tetapi dapat dipertanggungjawabkan kapabilitasnya untuk mengkondisikan bagian dalam bangunan tanpa menggunakan peralatan yang berlebihan.

Panas yang bergerak dari luar ke dalam bangunan masuk melalui proses konduksi dan radiasi. Konduksi adalah perpindahan kalor melalui zat penghantar tanpa disertai perpindahan bagian-bagian zat itu. Perpindahan kalor dengan cara konduksi pada umumnya terjadi pada zat padat. Sedangkan radiasi adalah perpindahan kalor tanpa memerlukan zat perantara. Pancaran kalor hanya terjadi dalam gas atau ruang hampa, misalnya penghantaran panas matahari ke 
bumi melalui ruang hampa udara ${ }^{2}$. Proses konduksi dan radiasi pada bangunan sangat erat kaitannya dengan komponen perhitungan OTTV.

Nilai OTTV dapat dihitung menggunakan rumus:

$$
\text { OTTV }=\alpha\left[U_{w} x(1-W W R)\right] x T D e k+U_{f} x W W R \times \Delta T+S C \times W W R \times S F
$$

Yang dapat diturunkan menjadi:

$$
\text { OTTV }=\frac{(\alpha x U w x A w x T D e k)+(U f x A f x \Delta T)+(S F x A f x S C)}{A i}
$$

Keterangan:

$W W R=$ Perbandingan dinding masif dan dinding transparan pada orientasi tsb

$A w=$ Luas dinding masif pada orientasi tsb

Af $=$ Luas dinding transparan pada orientasi tsb

$A i=$ Luas total seluruh dinding pada orientasi tsb

Komponen perhitungan OTTV dibagi menjadi tiga komponen yaitu perhitungan perpindahan kalor melalui konduksi material masif (nilai Uw material dinding), perpindahan kalor melalui konduksi material yang transparan (nilai WWR dan nilai Uf material transparan), dan perpindahan kalor melalui radiasi oleh material yang transparan (nilai SC).

\section{FAKTOR PENCAHAYAAN ALAMI PADA SIANG HARI ${ }^{3}$}

Kondisi pencahayaan alami pada bangunan dipengaruhi oleh tiga faktor yaitu komponen cahaya langit, komponen refleksi luar, dan komponen refleksi dalam. Komponen cahaya langit adalah komponen pencahayaan yang langsung datang dari cahaya langit. Komponen refleksi luar yaitu komponen pencahayaan yang berasal dari refleksi benda-benda yang berada di sekitar bangunan. Komponen refleksi dalam yaitu komponen pencahayaan yang berasal dari refleksi permukaan di dalam ruangan.

\section{KORELASI OTTV DAN PENCAHAYAAN ALAMI}

Korelasi antara OTTV dan pencahayaan alami dapat dilihat dari rumus perhitungan yang digunakan, yaitu sama-sama menggunakan faktor bukaan dinding.

Seluruh faktor yang mempengaruhi iluminasi pencahayaan alami dipengaruhi oleh bukaan pada bangunan, karena bukaan pada bangunan merupakan penyebab cahaya alami dapat masuk ke dalam bangunan. Hal ini dapat dilihat pada rumus untuk menghitung iluminasi cahaya alami yang langsung datang dari terang langit masuk ke dalam bangunan yaitu sebagai berikut:

$$
f l=\frac{1}{2 \pi}\left\{\arctan \frac{L}{D}-\frac{1}{\sqrt{1+\left(\frac{H}{D}\right)^{2}}} \arctan \frac{L_{D}}{\sqrt{1+\left(\frac{H}{D}\right)^{2}}}\right.
$$

Keterangan:

$L=$ Lebar lubang cahaya efektif

$H=$ Ting gi lubang cahaya efektif

$D=$ Jarak titik ukur dengan lubang cahaya

\footnotetext{
2 Pengertian Konduksi, Konveksi, dan Radiasi, diakses dari: www.pengertianahli.com/ 2013/11/pengertiankonduksi-konveksi-radiasi.html

${ }^{3}$ SNI 03-2396-2001 Tata Cara Perancangan Sistem Pencahayaan Alami pada Bangunan Gedung
} 
Pada perhitungan OTTV terdapat komponen luas dinding masif, luas dinding transparan, dan luas total seluruh dinding pada orientasi tersebut. Pada perhitungan pencahayaan alami yang langsung masuk ke dalam bangunan terdapat komponen lebar lubang cahaya efektif dan tinggi lubang cahaya efektif.

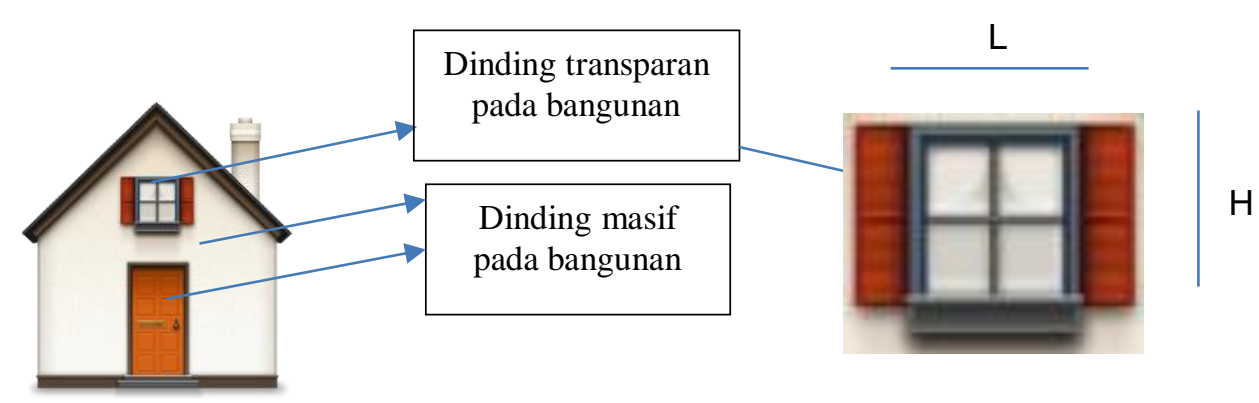

Figur 1. Ilustrasi Komponen Perhitungan OTTV dan Pencahayaan Alami (Sumber: http://brod32.ru)

Berdasarkan ilustrasi pada gambar, maka nilai OTTV dan nilai pencahayaan alami saling berhubungan karena keduanya bergantung pada komponen dinding transparan/komponen lubang cahaya efektif. Pada perhitungan OTTV, luas komponen dinding transparan dibandingkan dengan luas dinding keseluruhan sebagai nilai WWR kemudian dihitung menghasilkan nilai OTTV. Sedangkan pada perhitungan pencahayaaan alami, komponen dinding transparan tersebut dijabarkan menjadi lebar dan tinggi lubang cahaya efektif yang kemudian dimasukan ke dalam rumus perhitungan sehingga diperoleh nilai iluminasi pencahayaan alami pada suatu titik ukur.

\section{METODA PENELITIAN}

Jenis penelitian yang dilakukan adalah penelitian kuantitatif dengan metode penelitian menggunakan simulasi. Variabel simulasi yang dimanipulasi disebut sebagai variabel bebas, sedangkan variabel yang berubah karena hasil manipulasi variabel bebas disebut variabel terikat. Sebelum simulasi dilakukan, teori mengenai OTTV dianalisa terlebih dahulu untuk mengetahui variabel yang paling optimal untuk di optimalisasi.

Simulasi yang dilakukan pada penelitian ini menggunakan simulasi perhitungan nilai OTTV dan simulasi dengan program Dialux untuk mencari nilai perhitungan pencahayaan alami. Variabel bebas pada penelitian ini yaitu nilai WWR dan nilai Uf (jumlah panas yang melalui material transparan; $\mathrm{W} / \mathrm{m}^{2}$ ) pada material bangunan. Variabel terikat pada penelitian ini yaitu nilai OTTV dan nilai pencahayaan alami.

Penelitian dibagi menjadi dua tahap yaitu tahap pra-penelitian dan tahap penelitian. Tahap pra-penelitian merupakan proses penelitian terhadap nilai desain arsitektural Gedung 45 berdasarkan standard GREENSHIP NB 1.2. Tahap pra-penelitian dilakukan untuk mengetahui permasalahan yang ada pada Gedung 45 terkait dengan penilaian bangunan hijau. Setelah diketahui permasalahan yang ada pada Gedung 45, maka dilakukan penelitian terhadap salah satu permasalahan yaitu nilai OTTV. 
Nilai OTTV yang optimal tersebut selanjutnya digunakan untuk pengaturan desain fasad yang sesuai dengan nilai OTTV, nilai pencahayaan alami, dan sesuai dengan konfigurasi ruang di dalam bangunan.

\section{ANALISA \\ 4.1 DATA PENELITIAN}

Data Gedung 45 UNPAR yaitu sebagai berikut.

\section{Tabel 1. Data Gedung 45 UNPAR}

\begin{tabular}{|l|l|}
\hline Alamat & Jalan Ciumbuleuit no. 94 Bandung \\
\hline Luas UNPAR & $35514 \mathrm{~m}^{2}$ \\
\hline Luas RTH UNPAR & $6219.65 \mathrm{~m}^{2}$ \\
\hline Jumlah Lantai & 2 \\
\hline Luas Bangunan & $4600.67 \mathrm{~m}^{2}$ \\
\hline Luas Lantai 1 & $2276.67 \mathrm{~m}^{2}$ \\
\hline Luas Lantai 2 & $2324 \mathrm{~m}^{2}$ \\
\hline Luas B1/B2/B3 & $2684.68 \mathrm{~m}^{2}$ \\
\hline Luas Atap & $3012.41 \mathrm{~m}^{2}$ \\
\hline Fungsi Bangunan & Pendidikan \\
\hline Sistem Struktur & Struktur rigid frame \\
\hline \multirow{2}{*}{ Material Bangunan } & Kolom beton bertulang \\
\cline { 2 - 3 } & Balok beton bertulang \\
\cline { 2 - 3 } & Plat lantai beton bertulang \\
\cline { 2 - 3 } & Dinding bata ringan (hebel) dan kaca laminasi \\
\cline { 2 - 3 } & Penutup lantai keramik 60x60 \\
\hline \multirow{5}{*}{ Warna Bangunan } & Putih semi kilap \\
\hline
\end{tabular}
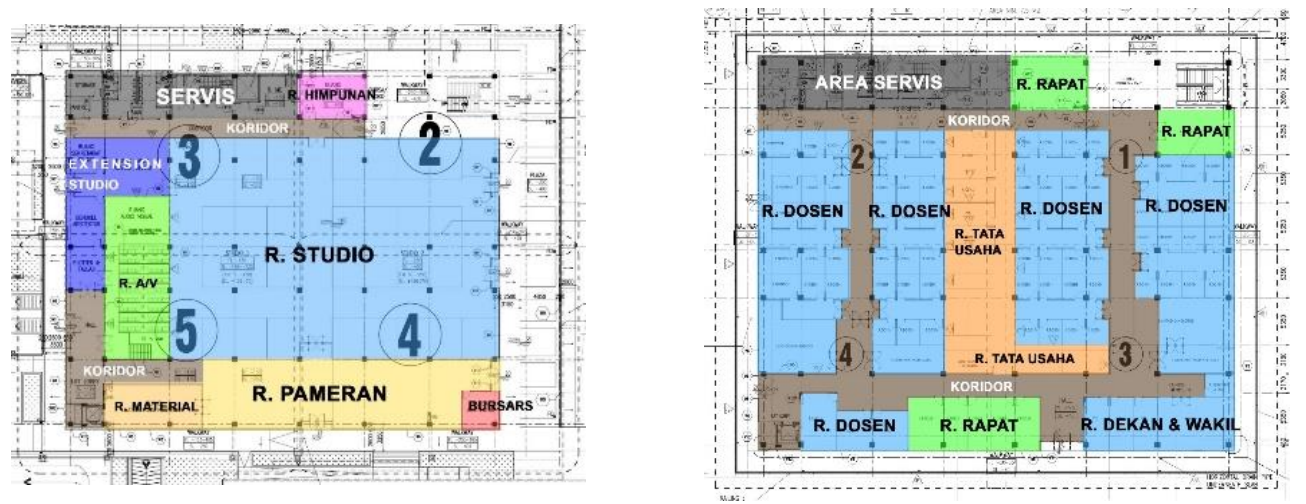

Figur 2. Denah Gedung 45

\section{Pola penataan ruang}

Gedung 45 pada area timur dimanfaatkan sebagai area servis, area lainnya berfungsi sebagai area fungsional bangunan. Pada lantai 1 terdapat ruang studio, area asisten dosen, ruang audio visual, ruang material, ruang pameran, kantin, dan ruang himpunan. 
Pola penataan ruang pada lantai 1A masih sama dengan lantai 1 , area timur dijadikan area servis. Selebihnya, ruang yang terletak pada lantai 1A yaitu ruang rapat, ruang dosen, ruang dekan, dan ruang tata usaha. Ruang dosen dan ruang rapat diletakkan pada bagian luar bangunan sehingga menerima cahaya matahari dan pemandangan ke luar gedung. Sedangkan ruang tata usaha terletak di tengah bangunan dan tidak mendapat cahaya alami langsung.

\section{Fasad}

Gedung 45 didominasi oleh bukaan dengan material kaca laminasi setinggi 3 meter pada lantai 1 dan lantai 1A. Jarak antar lantai (floor to floor) pada lantai 1 yaitu sebesar 5 meter, sedangkan pada lantai 1A 3.8 meter. Material yang digunakan yaitu beton ringan dan kaca laminasi sebagai material dinding pembatas ruang.
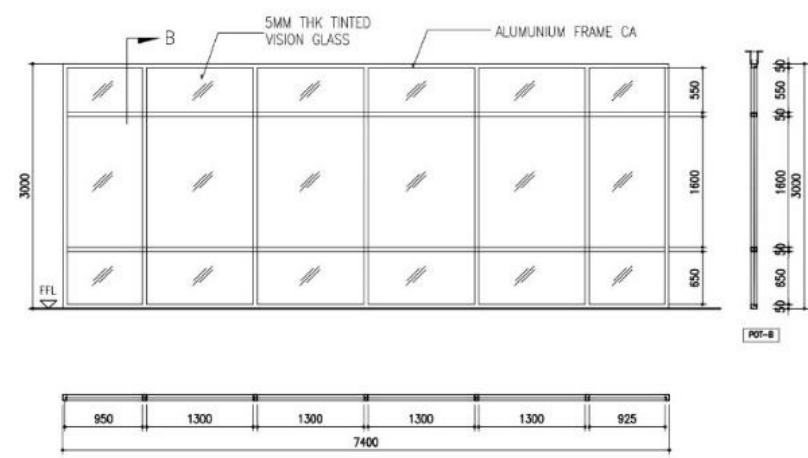

Figur 3. Detail Bukaan Gedung 45

\subsection{DATA BASELINE GEDUNG 45}

\section{NILAI OTTV BASELINE GEDUNG 45}

Berikut ini adalah nilai OTTV baseline Gedung 45 setelah melalui proses perhitungan OTTV:

Tabel 2. Nilai OTTV Baseline Gedung 45

\begin{tabular}{|c|c|c|c|}
\hline Orientasi / Lantai & $\begin{array}{c}\text { Nilai OTTV } \\
\text { (baseline) }\left(\mathbf{W} / \mathbf{m}^{2}\right)\end{array}$ & $\begin{array}{c}\text { Luas } \\
\text { permukaan } \\
\left.\text { fasad } \mathbf{( m}^{\mathbf{2}}\right)\end{array}$ & $\begin{array}{c}\text { OTTV/ Orientasi } \\
\text { (baseline) }(\mathbf{W})\end{array}$ \\
\hline Timur / 1 & 29.25 & 271 & 7926.74 \\
\hline Timur / 2 & 33.47 & 205.96 & 6894.27 \\
\hline Selatan / 1 & 28.18 & 224 & 6312.92 \\
\hline Selatan / 2 & 41.35 & 170.24 & 7040.09 \\
\hline Barat / 1 & 44.39 & 271 & 12028.79 \\
\hline Barat / 2 & 51.95 & 205.96 & 10699.38 \\
\hline Utara / 1 & 37.05 & 224 & 829.74 \\
\hline Utara / 2 & 48.41 & 170.24 & 8241.47 \\
\hline \multicolumn{4}{|l}{ OTTV Total $\left(\mathbf{W} / \mathbf{m}^{\mathbf{2}}\right)$} \\
\hline
\end{tabular}

Nilai OTTV baseline pada Gedung 45 yaitu $39.68 \mathrm{~W} / \mathrm{m} 2$, belum memenuhi kriteria GREENSHIP NB 1.2. Diperlukan penurunan hingga $35 \mathrm{~W} / \mathrm{m} 2$ untuk memenuhi kriteria GREENSHIP NB 1.2. 


\section{ILUMINASI PENCAHAYAAN ALAMI BASELINE GEDUNG 45}

Berikut ini adalah nilai iluminasi pencahayaan alami baseline Gedung 45 setelah melalui proses simulasi DIAlux.

\begin{tabular}{|c|c|c|c|c|c|}
\hline & $\begin{array}{c}\text { Luas } \\
\text { lantai } \\
\left(\mathrm{m}^{2}\right)\end{array}$ & $\begin{array}{c}30 \% \\
\text { luas } \\
\text { lantai } \\
\left(\mathrm{m}^{2}\right)\end{array}$ & $\begin{array}{c}\text { Area dengan } \\
\text { Iluminasi } \\
\text { pencahayaan alami } \\
300 \text { lux }\left(\mathrm{m}^{2}\right)\end{array}$ & $\begin{array}{c}\text { Nilai } \\
\text { WWR }\end{array}$ & Simulasi DIALux \\
\hline $\begin{array}{c}\text { Lantai } \\
\mathbf{1}\end{array}$ & 2276.67 & 683 & $\begin{array}{c}1162.27(51 \% \text { luas } \\
\text { lantai) }\end{array}$ & $45 \%$ & \\
\hline $\begin{array}{c}\text { Lantai } \\
\text { 1A }\end{array}$ & 2324 & 697.2 & $\begin{array}{c}850.77(37 \% \text { luas } \\
\text { lantai) }\end{array}$ & $61 \%$ & \\
\hline
\end{tabular}

\section{PENURUNAN NILAI OTTV BERDASARKAN VARIABEL SHADING COEFFICIENT}

Koefisien peneduh adalah koefisien yang diperoleh dengan membandingkan area yang diteduhi dengan panjang peneduh. Koefisien peneduh pada bangunan, dibandingkan dengan tabel koefisien peneduh pada SNI 03-6389-2011 tentang Konservasi Energi Selubung Bangunan pada Bangunan Gedung.

Pengaruh variabel koefisien peneduh terhadap penurunan nilai OTTV dapat dianalisa dengan mengkonversi tabel koefisien peneduh pada SNI 03-6389-2011 menjadi diagram garis. Bentuk diagram garis yang terbentuk dapat dijadikan kesimpulan mengenai tingkat efisiensi penurunan nilai OTTV berdasarkan koefisien peneduh bangunan.

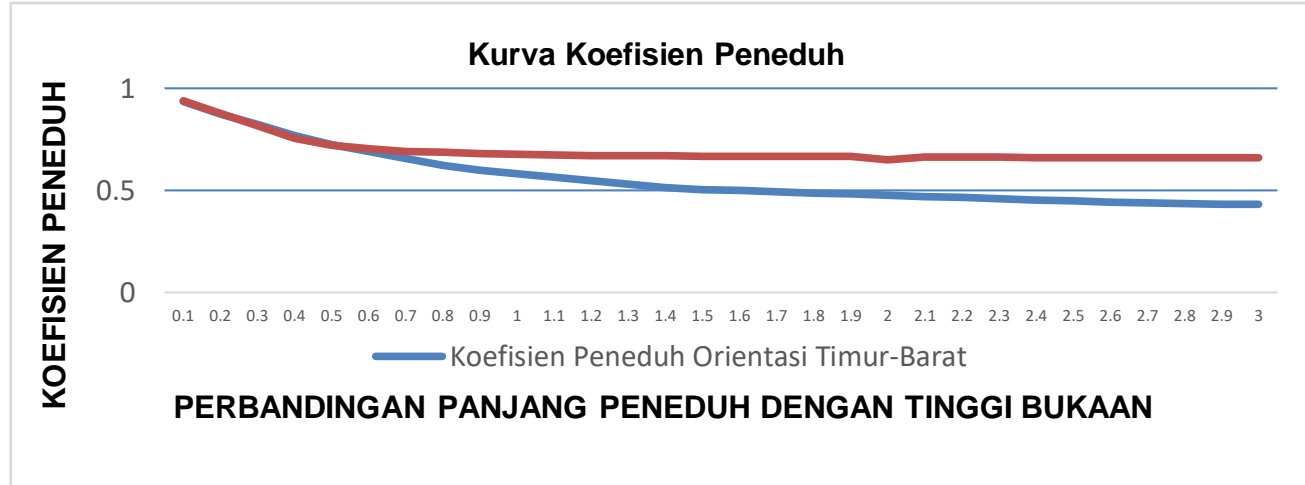

Figur 4. Diagram Perubahan Koefisien Peneduh terhadap Perbandingan Panjang Peneduh dengan Tinggi Bukaan

Bentuk kurva yang terjadi yang memperlihatkan hubungan antara koefisien peneduh dengan perbandingan tinggi bukaan dan panjang peneduh berupa kurva parabola terbalik. Berdasarkan kurva tersebut, efisiensi peneduh akan semakin berkurang apabila peneduh tersebut diperpanjang. Oleh karena itu, penurunan nilai OTTV berdasarkan variabel koefisien peneduh kurang efektif untuk menurunkan nilai OTTV karena terdapat titik batas dimana penambahan peneduh tidak dapat lagi memberi dampak yang signifikan pada nilai OTTV. Selain itu, penambahan panjang peneduh juga berkaitan dengan kemampuan struktural bangunan seperti batas panjang kantilever bangunan dan lainnya. 
Penambahan panjang peneduh pada bangunan yang sudah berdiri juga harus mempertimbangkan kondisi lingkungan sekitar. Pada Gedung 45 UNPAR, penambahan panjang peneduh dapat menimbulkan masalah dengan bangunan yang ada di sekitarnya. Panjang kantilever pada Gedung 45 juga sudah mencapai 3 meter, yang mendekati batas panjang kantilever beton bertulang yang efisien.

\section{PENURUNAN NILAI OTTV BERDASARKAN VARIABEL MATERIAL BUKAAN}

Material bukaan yang digunakan pada Gedung 45 yaitu tinted glass dengan sticker. Material ini memiliki Uf sebesar $5.28 \mathrm{~W} / \mathrm{m}^{2} \mathrm{~K}$, dan menghasilkan nilai OTTV sebesar 39.68 $\mathrm{W} / \mathrm{m}^{2}$. Untuk mengetahui material yang cocok untuk menurunkan nilai OTTV hingga mencapai tingkat 35 hingga $30 \mathrm{~W} / \mathrm{m}^{2}$, maka diperlukan perhitungan untuk mencari nilai Uf yang disarankan.

Tabel 3. Nilai Uf yang Disarankan untuk Setiap Orientasi

\begin{tabular}{|c|c|c|c|c|}
\hline Orientasi & Lantai & $\begin{array}{c}\text { Target } \\
\text { Penurunan }\end{array}$ & Nilai Uf (baseline) & $\begin{array}{c}\text { Nilai Uf } \\
\text { (disarankan) }\end{array}$ \\
\hline \multirow[t]{2}{*}{ Timur } & 1 & \multirow{2}{*}{$\begin{array}{c}30 \\
(5 \text { poin })\end{array}$} & 5.28 & 5.36 \\
\hline & $1 \mathrm{~A}$ & & 5.28 & 3.33 \\
\hline \multirow[t]{2}{*}{ Selatan } & 1 & \multirow{2}{*}{$\begin{array}{c}30 \\
\text { (5 Poin) }\end{array}$} & 5.28 & 5.73 \\
\hline & $1 \mathrm{~A}$ & & 5.28 & 1.50 \\
\hline \multirow[t]{2}{*}{ Barat } & 1 & \multirow{2}{*}{$\begin{array}{c}30 \\
\text { (5 Poin) }\end{array}$} & 5.28 & -0.43 \\
\hline & $1 \mathrm{~A}$ & & 5.28 & -1.19 \\
\hline \multirow[t]{2}{*}{ Utara } & 1 & \multirow{2}{*}{$\begin{array}{c}30 \\
\text { (5 Poin) }\end{array}$} & 5.28 & 2.09 \\
\hline & $1 \mathrm{~A}$ & & 5.28 & -0.66 \\
\hline \multicolumn{4}{|c|}{ Nilai Uf rata-rata $(+/-0.5)$} & 1.97 \\
\hline
\end{tabular}

Nilai Uf rata-rata yang disarankan untuk penurunan nilai OTTV dengan target $30 \mathrm{~W} / \mathrm{m}^{2}$ yaitu $1.97 \mathrm{~W} / \mathrm{m}^{2} \mathrm{~K}$. Sedangkan nilai Uf baseline dari material bukaan pada Gedung 45 yaitu $5.28 \mathrm{~W} / \mathrm{m}^{2} \mathrm{~K}$. Untuk menurunkan nilai OTTV juga diperlukan penggantian seluruh material bukaan pada Gedung 45 sebesar $912.62 \mathrm{~m}^{2}$.

Material kaca yang tersedia di pasaran memiliki nilai Uf terkecil hingga $1.8 \mathrm{~W} / \mathrm{m}^{2} \mathrm{~K} .{ }^{4}$ Apabila mengganti seluruh material bukaan dengan kaca yang memiliki nilai Uf $1.8 \mathrm{~W} / \mathrm{m}^{2} \mathrm{~K}$, maka nilai OTTV Gedung 45 yaitu sebagai berikut:

Tabel 4. Nilai OTTV berdasarkan Optimalisasi nilai Uf

\begin{tabular}{|c|c|c|c|}
\hline Orientasi / Lantai & $\begin{array}{c}\text { Nilai OTTV } \\
\text { (baseline) }\left(\mathrm{W} / \mathrm{m}^{2}\right)\end{array}$ & Luas bukaan $\left(\mathrm{m}^{2}\right)$ & Nilai OTTV $\left(\mathrm{W} / \mathrm{m}^{2}\right)$ \\
\hline Timur / 1 & 29.87 & 90.59 & 23.55 \\
\hline Timur / 2 & 34.29 & 90.59 & 25.97 \\
\hline Selatan / 1 & 29 & 99.18 & 20.63 \\
\hline Selatan / 2 & 42.59 & 113.64 & 29.97 \\
\hline Barat / 1 & 45.38 & 146.01 & 35.20 \\
\hline Barat / 2 & 53.28 & 148.07 & 39.69 \\
\hline Utara / 1 & 49.63 & 112.07 & 28.52 \\
\hline Utara / 2 & 48.41 & 112.47 & 37.15 \\
\hline
\end{tabular}

${ }^{4}$ AGC Group. Planibel Glass [Brosur], diakses tanggal 27 April 2017 pukul 19.06 dari: http://asahimas.arwuda.com/id/produk/kaca-lembaran/brosur/ 


\begin{tabular}{|c|c|c|}
\hline Total luas bukaan & 912.62 & \\
\hline \multicolumn{2}{|c|}{ OTTV Total $\left(\mathrm{W} / \mathrm{m}^{2}\right)$} & 29.78 \\
\hline
\end{tabular}

Penggunaan kaca dengan nilai Uf sebesar $1.8 \mathrm{~W} / \mathrm{m}^{2} \mathrm{~K}$ dapat menurunkan nilai OTTV hingga $29.78 \mathrm{~W} / \mathrm{m}^{2}$. Penggunaan kaca low-E dapat menjadi salah satu alternatif untuk menurunkan nilai OTTV tanpa mengubah fasad dan tidak mengganggu iluminasi cahaya alami yang masuk ke dalam bangunan. Tetapi membutuhkan biaya yang cukup besar. Selain itu, terjadi aktivitas pembongkaran kaca yang telah dipakai sebelumnya. Sehingga akan menimbulkan banyak material kaca sisa yang tidak dipakai dan memiliki resiko menjadi sampah material bangunan.

\section{PENURUNAN NILAI OTTV BERDASARKAN VARIABEL WWR}

Nilai OTTV dapat diturunkan dengan menurunkan nilai WWR pada bangunan. WWR diturunkan dengan menutup sebagian bukaan transparan pada bangunan dengan material lain.

Bukaan transparan pada Gedung 45 ditutup menggunakan material panel Glassfibre Reinforced Cement (GRC) setebal $8 \mathrm{~mm}$. Pemilihan panel GRC sebagai material penutup bukaan yaitu karena GRC yang memiliki sifat tahan air, kuat, dapat dikerjakan dengan cepat, dan cocok untuk di pasang pada area luar bangunan.

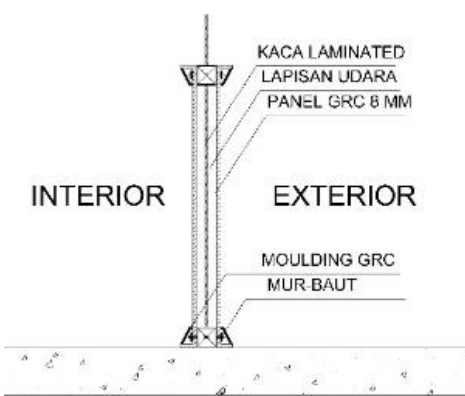

Figur 5. Teknik Pemasangan Penutup Bukaan

Karena terdiri dari dua material masif (material dinding dan material penutup bukaan), maka rumus OTTV yang digunakan yaitu sebagai berikut:

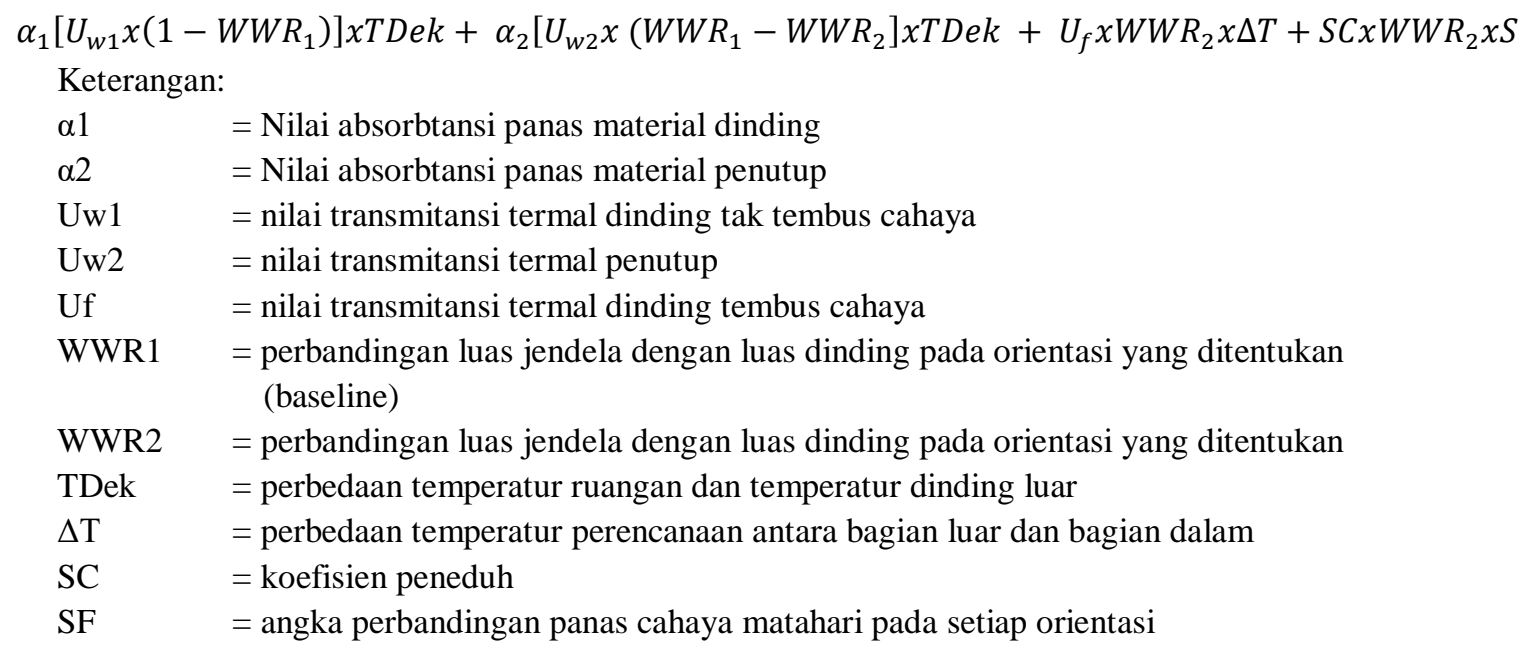

Rumus OTTV tersebut terbagi menjadi 4 bagian yaitu: 
$\alpha_{1}\left[U_{w 1} x\left(1-W W R_{1}\right)\right] x T D e k$; untuk menghitung nilai konduktivitas termal melalui elemen masif eksisting pada bangunan (dinding beton ringan) pada Gedung 45. $1-\boldsymbol{W} \boldsymbol{W} \boldsymbol{R}_{\mathbf{1}}$ pada rumus adalah Atau selisih antara luas bidang terbuka dengan luas dinding.

$\boldsymbol{\alpha}_{\mathbf{2}}\left[\boldsymbol{U}_{\boldsymbol{w} 2} \boldsymbol{x}\left(\boldsymbol{W} \boldsymbol{W} \boldsymbol{R}_{\mathbf{1}}-\boldsymbol{W} \boldsymbol{W} \boldsymbol{R}_{\mathbf{2}}\right] \boldsymbol{x} \boldsymbol{T} \boldsymbol{D e k} ;\right.$ untuk menghitung nilai konduktivitas termal melalui elemen penutup bukaan yang digunakan untuk menurunkan nilai OTTV pada Gedung 45. Penutup yang digunakan yaitu material panel GRC dengan rongga udara.

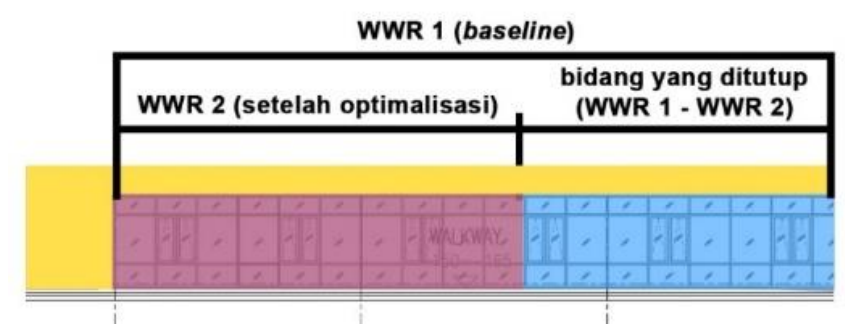

Figur 6 Visualisasi WWR Setelah dan Sebelum Ditutup

$\boldsymbol{U}_{\boldsymbol{f}} \boldsymbol{x} \boldsymbol{W} \boldsymbol{W} \boldsymbol{R}_{\mathbf{2}} \boldsymbol{x} \boldsymbol{\Delta} \boldsymbol{T}$; untuk menghitung nilai konduktivitas termal pada material transparan (bukaan) Gedung 45.

$\boldsymbol{S C} \boldsymbol{C} \boldsymbol{W} \boldsymbol{W} \boldsymbol{R}_{2} \boldsymbol{x} \boldsymbol{S} \boldsymbol{F}$; untuk menghitung nilai radiasi termal yang masuk ke dalam Gedung 45 .

\section{STRATEGI OPTIMALISASI NILAI WWR}

Tahapan yang dilakukan untuk mengoptimalisasi nilai WWR yaitu:

a. Melakukan analisis terkait dengan fungsi ruang di dalam bangunan yang tidak terlalu membutuhkan penacahayaan alami karena bukan ruang yang digunakan sebagai area aktivitas dalam waktu lama seperti ruang pameran, lounge, dan hall lift.Bukaan pada ruang yang tidak mewadahi aktivitas yang berlangsung lama tersebut akan dioptimalisasi dengan melakukan penutupan bukaan yang ada.

b. Apabila nilai WWR masih belum memenuhi nilai yang disarankan, maka akan dilakukan penutupan pada bagian bawah bukaan sebesar $65 \mathrm{~cm}$ sesuai dengan modul jendela, sehingga cahaya matahari dapat tetap masuk dan pengguna bangunan dapat memperoleh outside view.

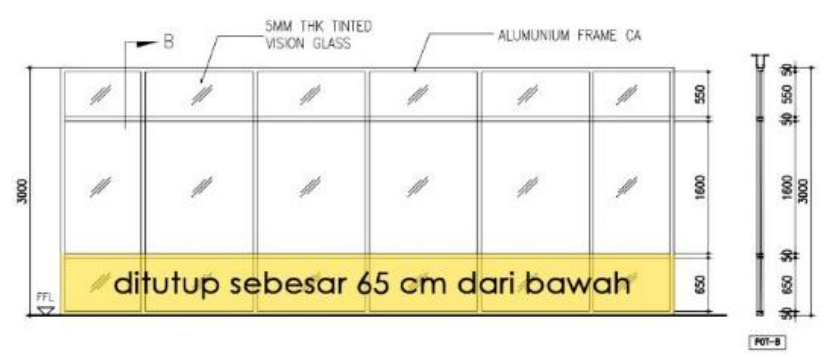

Figur 7. Ilustrasi Penutupan Bukaan

OPTIMALISASI NILAI WWR DENGAN TARGET NILAI OTTV 35 W/M2

\begin{tabular}{|c|c|}
\hline Fasad Baseline & Fasad setelah optimalisasi \\
\hline & Timur \\
\hline
\end{tabular}




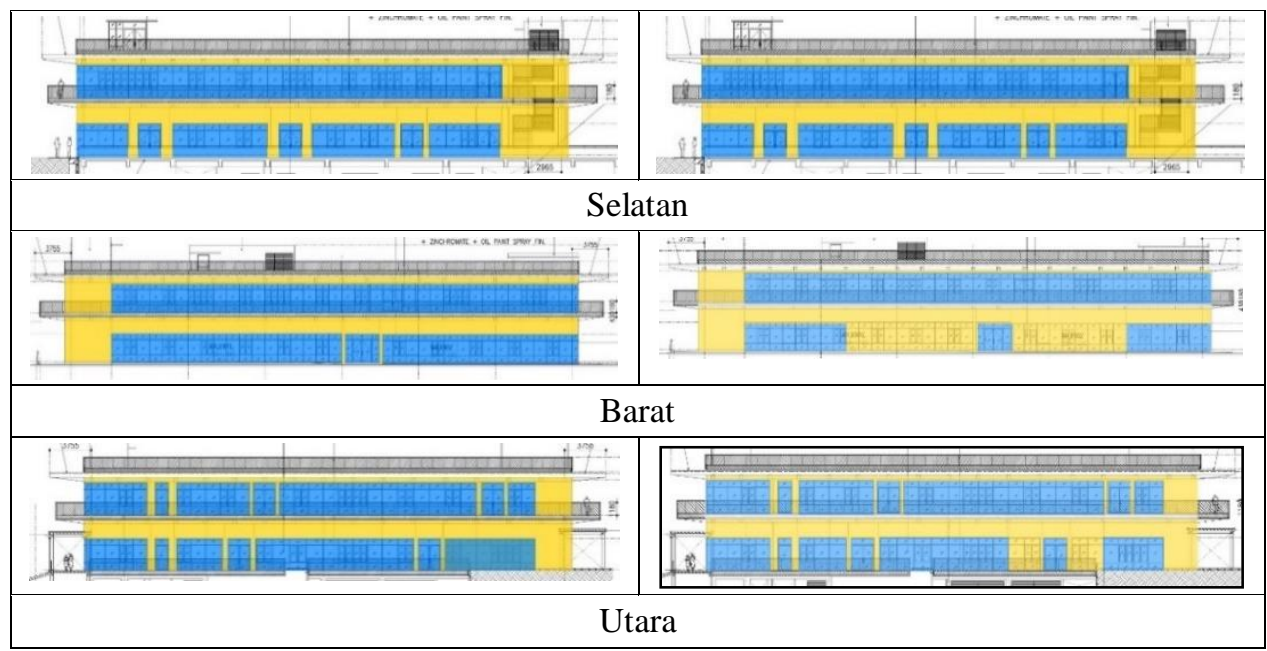

Figur 8. Optimalisasi Fasad dengan Target OTTV $35 \mathrm{~W} / \mathrm{m}^{2}$

Dilakukan penutupan bukaan pada orientasi barat dan utara lantai 1. Area tersebut merupakan area ruang pameran pada Gedung 45 dan lounge menuju ruang audiovisual pada Gedung 45. Kedua ruang tersebut tidak membutuhkan pencahayaan alami karena merupakan ruang dengan orientasi ke dalam bangunan dan tidak mewadahi aktivitas yang dilakukan dalam waktu lama.

Tabel 5. Nilai OTTV Setelah Optimalisasi dengan Target OTTV 35 W/m2

\begin{tabular}{|c|c|c|c|c|c|}
\hline $\begin{array}{c}\text { Orientasi / } \\
\text { Lantai }\end{array}$ & $\begin{array}{c}\text { Nilai OTTV } \\
\text { (baseline) } \\
\left(\mathbf{W} / \mathbf{m}^{2}\right)\end{array}$ & $\begin{array}{l}\text { Nilai } \\
\text { OTTV } \\
\left(\mathrm{W} / \mathbf{m}^{2}\right)\end{array}$ & $\begin{array}{c}\text { Luas } \\
\text { permukaan } \\
\text { fasad }\left(\mathbf{m}^{2}\right)\end{array}$ & $\begin{array}{c}\text { OTTV / } \\
\text { Orientasi } \\
\text { (baseline) }(W)\end{array}$ & $\begin{array}{l}\text { OTTV/ } \\
\text { Orientasi } \\
\text { (W) }\end{array}$ \\
\hline Timur / 1 & 29.87 & 29.87 & 271 & 5702.75 & 8094.33 \\
\hline Timur / 2 & 34.29 & 34.29 & 205.96 & 7061.86 & 7061.86 \\
\hline Selatan / 1 & 29.00 & 29.00 & 224 & 6496.41 & 6496.41 \\
\hline Selatan / 2 & 42.59 & 42.59 & 170.24 & 7250.32 & 7250.32 \\
\hline Barat / 1 & 45.38 & 45.38 & 271 & 1298.91 & 5027.36 \\
\hline Barat / 2 & 53.28 & 53.28 & 205.96 & 10973.30 & 10973.30 \\
\hline Utara / 1 & 37.97 & 37.97 & 224 & 8506.07 & 6809.21 \\
\hline Utara / 2 & 49.63 & 49.63 & 170.24 & 8449.54 & 8449.54 \\
\hline \multicolumn{3}{|c|}{ Subtotal } & 1742.4 & 66739.17 & 60162.33 \\
\hline \multicolumn{4}{|c|}{ OTTV Total $\left(\mathbf{W} / \mathbf{m}^{2}\right)$} & 38.30 & 34.53 \\
\hline
\end{tabular}

Dari hasil perhitungan OTTV, nilai OTTV berhasil diturunkan hingga mencapai nilai $34.53 \mathrm{~W} / \mathrm{m}^{2}$ dari nilai awal $39.68 \mathrm{~W} / \mathrm{m}^{2}$, sehingga Gedung 45 dapat memenuhi kriteria prasyarat EEC P2 dan memperoleh 3 poin.

Iluminasi pencahayaan alami pada bangunan disimulasi menggunakan program DIAlux, berdasarkan hasil simulasi terhadap data WWR hasil optimalisasi, maka diperoleh hasil sebagai berikut:

Tabel 6. Iluminasi Pencahayaan Alami Setelah Optimalisasi dengan Target OTTV 35 W/m²

\begin{tabular}{|c|c|c|}
\hline & $\begin{array}{c}\text { Luas pencahayaan alami } \\
\text { (baseline) }\end{array}$ & Luas pencahayaan alami \\
\hline
\end{tabular}




\begin{tabular}{|c|c|c|}
\hline \multirow[t]{2}{*}{ Lantai 1} & 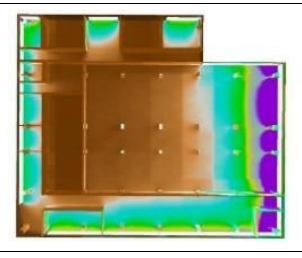 & 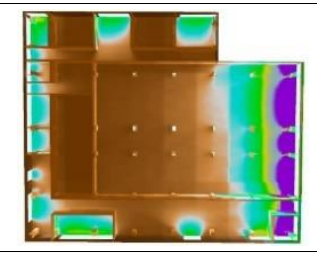 \\
\hline & $1162.27(51 \%)$ & $1004.14(40.6 \%)$ \\
\hline \multirow[t]{2}{*}{ Lantai 1A } & 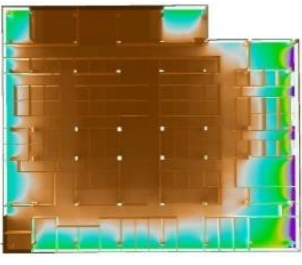 & 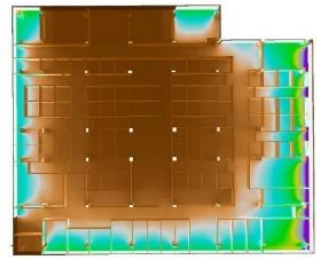 \\
\hline & $850.77(37 \%)$ & $850.77(37 \%)$ \\
\hline
\end{tabular}

Berdasarkan proses simulasi tersebut, maka bangunan masih memenuhi standard $30 \%$ luas setiap lantai bangunan memiliki iluminasi pencahayaan alami minimum sebesar 300 lux.

\section{OPTIMALISASI NILAI WWR DENGAN TARGET NILAI OTTV 32.5 W/M²}

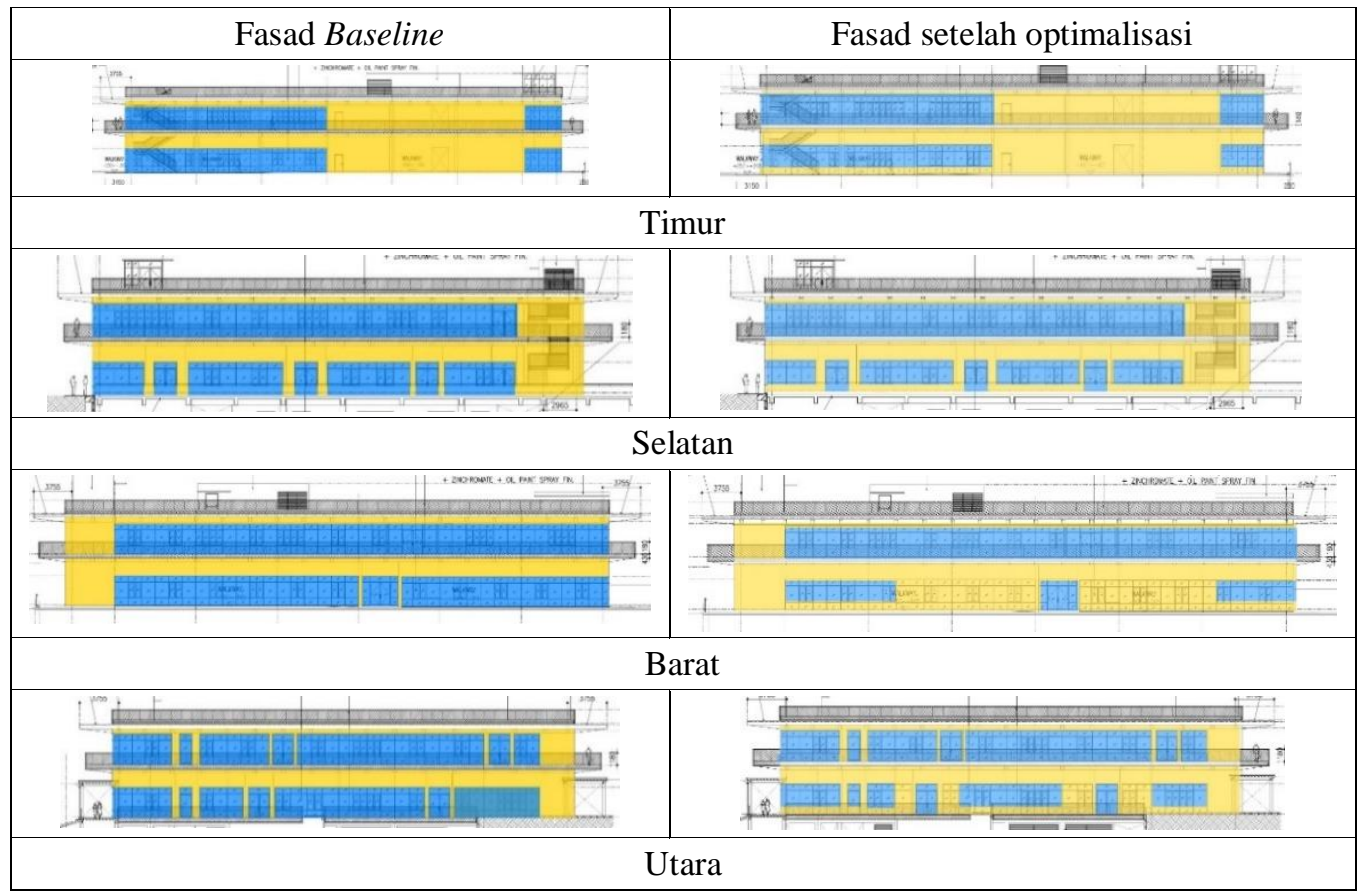

Figur 9. Optimalisasi Fasad dengan target OTTV $32.5 \mathrm{~W} / / \mathrm{m}^{2}$

Seluruh bukaan lantai 1 Gedung 45 diberi penutup pada $65 \mathrm{~cm}$ dari bawah bukaan sebagai upaya untuk menurunkan nilai OTTV dengan target $32.5 \mathrm{~W} / \mathrm{m}^{2}$. Penutupan bukaan yang pada seluruh orientasi juga merupakan upaya untuk mempertahankan karakter Gedung 45 yang memiliki bukaan menerus pada bagian sudut bangunan.

Tabel 7. Nilai OTTV Setelah Optimalisasi dengan Target OTTV $32.5 \mathrm{~W} / \mathrm{m}^{2}$ 


\begin{tabular}{|c|c|c|c|c|c|}
\hline $\begin{array}{c}\text { Orientasi / } \\
\text { Lantai }\end{array}$ & $\begin{array}{c}\text { Nilai OTTV } \\
\text { (baseline) } \\
\left(\mathbf{W} / \mathbf{m}^{2}\right)\end{array}$ & $\begin{array}{l}\text { Nilai } \\
\text { OTTV } \\
\left(\mathbf{W} / \mathbf{m}^{2}\right)\end{array}$ & $\begin{array}{c}\text { Luas } \\
\text { permukaan } \\
\text { fasad }\left(\mathbf{m}^{2}\right)\end{array}$ & $\begin{array}{c}\text { OTTV/ } \\
\text { Orientasi } \\
\text { (baseline) (W) }\end{array}$ & $\begin{array}{l}\text { OTTV/ } \\
\text { Orientasi } \\
\text { (W) }\end{array}$ \\
\hline Timur / 1 & 29.87 & 24.52 & 271 & 5702.75 & 6646.13 \\
\hline Timur / 2 & 34.29 & 34.29 & 205.96 & 7061.86 & 7061.86 \\
\hline Selatan / 1 & 29.00 & 24.68 & 224 & 6496.41 & 5528.47 \\
\hline Selatan / 2 & 42.59 & 42.59 & 170.24 & 7250.32 & 7250.32 \\
\hline Barat / 1 & 45.38 & 16.21 & 271 & 1298.91 & 4391.94 \\
\hline Barat / 2 & 53.28 & 53.28 & 205.96 & 10973.30 & 10973.30 \\
\hline Utara / 1 & 37.97 & 25.75 & 224 & 8506.07 & 5767.84 \\
\hline Utara / 2 & 49.63 & 49.63 & 170.24 & 8449.54 & 8449.54 \\
\hline \multicolumn{3}{|c|}{ Subtotal } & 1742.4 & 66739.17 & 56069.41 \\
\hline \multicolumn{4}{|c|}{ OTTV Total $\left(\mathrm{W} / \mathbf{m}^{2}\right)$} & 38.30 & 32.18 \\
\hline
\end{tabular}

Dari hasil perhitungan OTTV, nilai OTTV berhasil diturunkan hingga mencapai nilai $32.24 \mathrm{~W} / \mathrm{m}^{2}$ dari nilai awal $39.68 \mathrm{~W} / \mathrm{m}^{2}$, sehingga Gedung 45 dapat memenuhi kriteria EEC P2 dan memperoleh 4 poin.

Iluminasi pencahayaan alami pada bangunan disimulasi menggunakan program DIAlux, berdasarkan hasil simulasi terhadap data WWR hasil optimalisasi, maka diperoleh hasil sebagai berikut:

Tabel 8. Iluminasi Pencahayaan Alami Setelah Optimalisasi dengan Target OTTV 32.5 W/m²

\begin{tabular}{|c|c|c|}
\hline & $\begin{array}{c}\text { Luas pencahayaan alami } \\
\text { (baseline) }\end{array}$ & Luas pencahayaan alami \\
\hline \multirow[t]{2}{*}{ Lantai 1} & HPB & 居司 \\
\hline & $1162.27(51 \%)$ & $924.33(39.2 \%)$ \\
\hline \multirow[t]{3}{*}{ Lantai 1A } & & \\
\hline & Enasis & Ex-min \\
\hline & $850.77(37 \%)$ & $850.77(37 \%)$ \\
\hline
\end{tabular}

Luas lantai yang memiliki iluminasi pencahayaan lebih dari 300 lux yaitu sebesar $39.2 \%$ dan 37\% pada lantai 1 dan 1A, sehingga masih memenuhi kriteria GREENSHIP NB 1.2 yaitu minimum 30\% luas lantai memiliki iluminasi minimum 300 lux.

\section{OPTIMALISASI NILAI WWR DENGAN TARGET NILAI OTTV 30 W/M2}

\begin{tabular}{|c|c|}
\hline Fasad Baseline & Fasad setelah optimalisasi \\
\hline & Timur \\
\hline
\end{tabular}




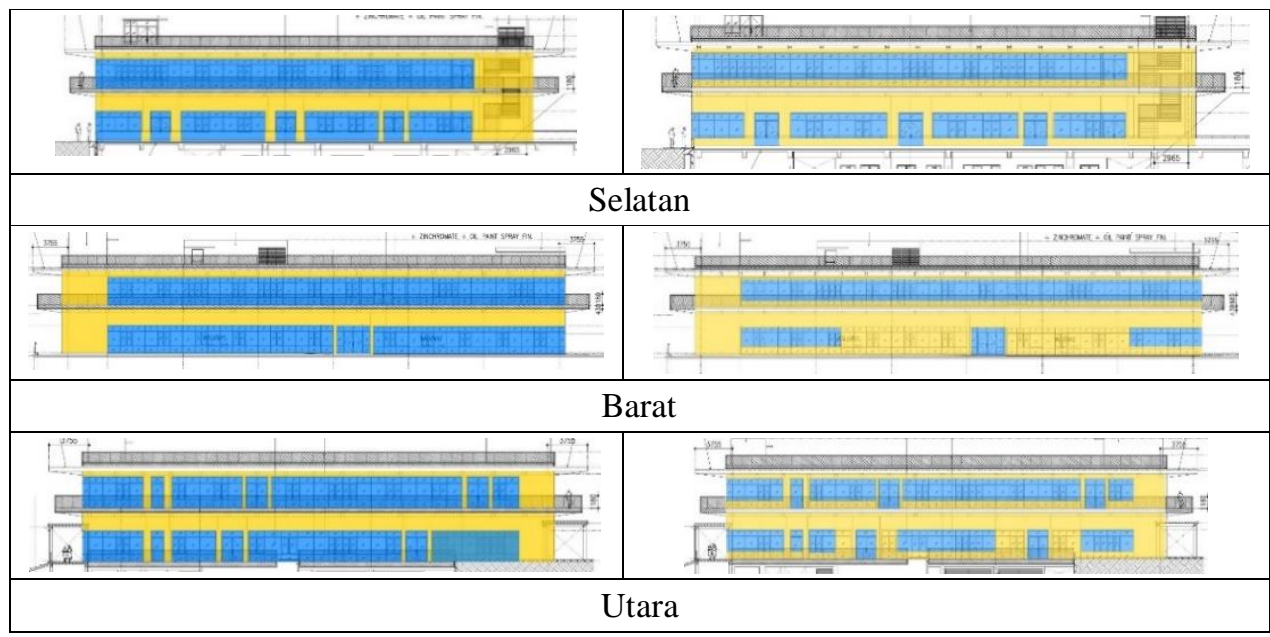

Figur 10. Optimalisasi Fasad dengan Target OTTV $30 \mathrm{~W} / \mathrm{m}^{2}$

Seluruh bukaan pada lantai 1 dan lantai 1 A diberi penutup untuk memperkecil nilai WWR bangunan. Penutup diletakan pada $65 \mathrm{~cm}$ dari bawah bukaan.

Tabel 9. Nilai OTTV Setelah Optimalisasi dengan Target OTTV $30 \mathrm{~W} / \mathrm{m}^{2}$

\begin{tabular}{|c|c|c|c|c|c|}
\hline $\begin{array}{l}\text { Orientasi / } \\
\text { Lantai }\end{array}$ & $\begin{array}{c}\text { Nilai OTTV } \\
\text { (baseline) } \\
\left(\mathbf{W} / \mathbf{m}^{2}\right)\end{array}$ & $\begin{array}{c}\text { Nilai } \\
\text { OTTV } \\
\left(\mathrm{W} / \mathbf{m}^{2}\right)\end{array}$ & $\begin{array}{l}\text { Luas } \\
\text { permukaan } \\
\text { fasad }\left(\mathbf{m}^{2}\right)\end{array}$ & $\begin{array}{c}\text { OTTV/ } \\
\text { Orientasi } \\
\text { (baseline) }(\mathbf{W})\end{array}$ & $\begin{array}{c}\text { OTTV/ } \\
\text { Orientasi } \\
(W)\end{array}$ \\
\hline Timur / 1 & 29.87 & 24.52 & 271 & 5702.75 & 6646.13 \\
\hline Timur / 2 & 34.29 & 27.94 & 205.96 & 7061.86 & 5753.98 \\
\hline Selatan / 1 & 29.00 & 24.68 & 224 & 6496.41 & 5528.47 \\
\hline Selatan / 2 & 42.59 & 34.74 & 170.24 & 7250.32 & 5914.38 \\
\hline Barat / 1 & 45.38 & 16.21 & 271 & 1298.91 & 4391.94 \\
\hline Barat / 2 & 53.28 & 42.69 & 205.96 & 10973.30 & 8791.74 \\
\hline Utara / 1 & 37.97 & 25.75 & 224 & 8506.07 & 5767.84 \\
\hline Utara / 2 & 49.63 & 421.58 & 170.24 & 8449.54 & 7079.30 \\
\hline \multicolumn{3}{|c|}{ Subtotal } & 1742.4 & 66739.17 & 49873.78 \\
\hline \multicolumn{4}{|c|}{ OTTV Total $\left(\mathrm{W} / \mathrm{m}^{2}\right)$} & $\mathbf{3 8 . 3 0}$ & 28.62 \\
\hline
\end{tabular}

Dari hasil perhitungan OTTV, nilai OTTV berhasil diturunkan hingga mencapai nilai $29.16 \mathrm{~W} / \mathrm{m}^{2}$ dari nilai awal $39.68 \mathrm{~W} / \mathrm{m}^{2}$, sehingga Gedung 45 dapat memenuhi kriteria EEC P2 dan memperoleh 5 poin.

Iluminasi pencahayaan alami pada bangunan disimulasi menggunakan program DIAlux, berdasarkan hasil simulasi terhadap data WWR hasil optimalisasi, maka diperoleh hasil sebagai berikut.

Tabel 10. Iluminasi Pencahayaan Alami Setelah Optimalisasi dengan Target OTTV 35 W/m²

\begin{tabular}{|c|c|c|}
\hline & $\begin{array}{c}\text { Luas pencahayaan alami } \\
\text { (baseline) }\end{array}$ & Luas pencahayaan alami \\
\hline
\end{tabular}




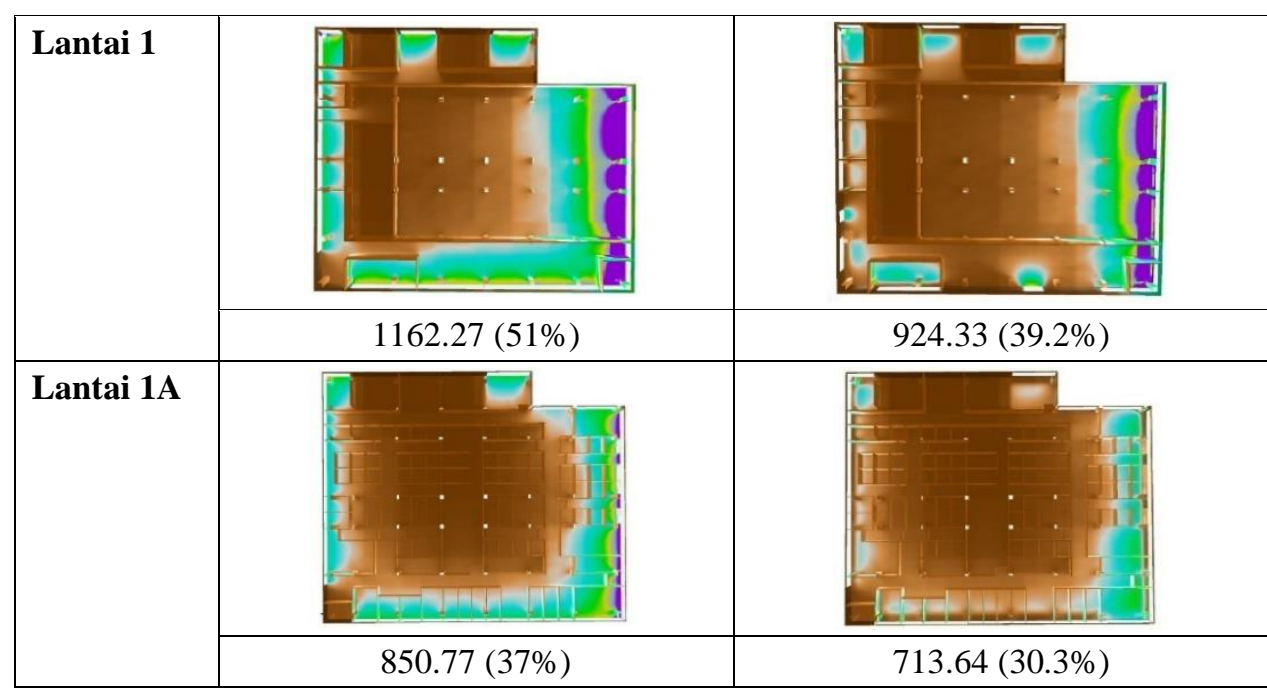

Luas lantai yang memiliki iluminasi pencahayaan lebih dari 300 lux yaitu sebesar $39.2 \%$ dan $30.3 \%$ pada lantai 1 dan 1A, sehingga masih memenuhi kriteria GREENSHIP NB 1.2 yaitu minimum $30 \%$ luas lantai memiliki iluminasi minimum 300 lux.

\section{Rangkuman Optimalisasi WWR terhadap Nilai OTTV dan Pencahayaan Alami} berikut:

Seluruh proses optimalisasi WWR yang telah diuraikan di atas dirangkum pada tabel

Tabel 11. Tabulasi Hasil Optimalisasi Nilai WWR terhadap Nilai OTTV

\begin{tabular}{|c|c|c|c|c|c|c|c|c|c|}
\hline \multicolumn{10}{|c|}{ Nilai OTTV } \\
\hline & & \multicolumn{2}{|c|}{ BASELINE } & \multicolumn{2}{|c|}{$\begin{array}{c}\text { Target: } 35 \\
\mathrm{~W} / \mathrm{m}^{2}\end{array}$} & \multicolumn{2}{|c|}{$\begin{array}{c}\text { Target: } 32.5 \\
\text { W/m² }\end{array}$} & \multicolumn{2}{|c|}{ Target: $30 \mathrm{~W} / \mathrm{m}^{2}$} \\
\hline $\begin{array}{l}\text { ORIENT } \\
\text { ASI }\end{array}$ & $\begin{array}{r}\text { LAN } \\
\text { TAI }\end{array}$ & $\begin{array}{c}\text { WW } \\
\mathbf{R}\end{array}$ & $\begin{array}{l}\text { OTTV } \\
\left(W / m^{2}\right)\end{array}$ & $\begin{array}{c}\text { WW } \\
\mathbf{R}\end{array}$ & $\begin{array}{l}\text { OTTV } \\
\left(\mathbf{W} / \mathbf{m}^{2}\right)\end{array}$ & $\begin{array}{c}\text { WW } \\
\mathbf{R}\end{array}$ & $\begin{array}{c}\text { OTTV } \\
\left(\mathbf{W} / \mathbf{m}^{2}\right)\end{array}$ & WWR & $\begin{array}{l}\text { OTTV } \\
\left(\mathbf{W} / \mathbf{m}^{2}\right)\end{array}$ \\
\hline \multirow[t]{2}{*}{ Timur } & 1 & $33 \%$ & 29.87 & $33 \%$ & 29.87 & $26 \%$ & 24.52 & $26 \%$ & 24.52 \\
\hline & $1 \mathrm{~A}$ & $44 \%$ & 34.29 & $44 \%$ & 34.29 & $44 \%$ & 34.29 & $34 \%$ & 27.94 \\
\hline \multirow[t]{2}{*}{ Selatan } & 1 & $44 \%$ & 29.00 & $44 \%$ & 29.00 & $37 \%$ & 24.68 & $37 \%$ & 24.68 \\
\hline & $1 \mathrm{~A}$ & $67 \%$ & 42.5 & $67 \%$ & 42.5 & $67 \%$ & 42.5 & $52 \%$ & 34.74 \\
\hline \multirow[t]{2}{*}{ Barat } & 1 & $54 \%$ & 45.38 & $18 \%$ & 18.55 & $15 \%$ & 16.21 & $15 \%$ & 16.21 \\
\hline & $1 \mathrm{~A}$ & $72 \%$ & 53.28 & $72 \%$ & 53.28 & $72 \%$ & 53.28 & $56 \%$ & 42.69 \\
\hline \multirow[t]{3}{*}{ Utara } & 1 & $50 \%$ & 37.97 & $39 \%$ & 30.40 & $32 \%$ & 25.75 & $32 \%$ & 25.75 \\
\hline & $1 \mathrm{~A}$ & $66 \%$ & 49.63 & $66 \%$ & 49.63 & $66 \%$ & 49.63 & $54 \%$ & 41.58 \\
\hline & & $\begin{array}{c}\text { Tota } \\
1\end{array}$ & 39.68 & Total & 34.53 & Total & 32.18 & Total & 28.62 \\
\hline \multicolumn{2}{|c|}{ Pencapaian } & \multicolumn{2}{|c|}{$\begin{array}{c}\text { Tidak } \\
\text { memenuhi } \\
\text { prasyarat }\end{array}$} & \multicolumn{2}{|c|}{$\begin{array}{c}\text { Memenuhi } \\
\text { prasyarat }\end{array}$} & \multicolumn{2}{|c|}{$\begin{array}{c}\text { Memenuhi } \\
\text { prasyarat }\end{array}$} & \multicolumn{2}{|c|}{$\begin{array}{c}\text { Memenuhi } \\
\text { prasyarat }\end{array}$} \\
\hline \multicolumn{2}{|c|}{ Perolehan poin } & \multicolumn{2}{|c|}{0} & \multicolumn{2}{|c|}{3} & \multicolumn{2}{|c|}{4} & \multicolumn{2}{|c|}{5} \\
\hline
\end{tabular}

Hal ini dilakukan dengan memperkecil nilai WWR pada lantai 1 dan lantai 1A Gedung 45.

Tabel 12. Tabulasi Hasil Optimalisasi Nilai WWR terhadap Nilai OTTV 


\begin{tabular}{|c|c|c|c|c|c|c|c|c|}
\hline \multicolumn{9}{|c|}{ Persentase Luas Ruangan dengan Iluminasi Pencahayaan Alami Lebih dari 300 lux } \\
\hline & \multicolumn{2}{|c|}{ BASELINE } & \multicolumn{2}{|c|}{ Target: $35 \mathrm{~W} / \mathrm{m}^{2}$} & \multicolumn{2}{|c|}{$\begin{array}{c}\text { Target: } 32.5 \\
\mathrm{~W} / \mathrm{m}^{2}\end{array}$} & \multicolumn{2}{|c|}{$\begin{array}{c}\text { Target: } 30 \\
\mathrm{~W} / \mathrm{m}^{2}\end{array}$} \\
\hline Lantai & WWR & $\%$ & WWR & $\%$ & WWR & $\%$ & WWR & $\%$ \\
\hline 1 & 0.45 & $51 \%$ & 0.35 & $40.6 \%$ & $0.28 \%$ & $39.2 \%$ & 0.28 & $39.2 \%$ \\
\hline $1 \mathrm{~A}$ & 0.61 & $37 \%$ & 0.61 & $37 \%$ & $0.61 \%$ & $37 \%$ & 0.50 & $30.3 \%$ \\
\hline Pencapaian & \multicolumn{2}{|c|}{$\begin{array}{c}\text { Memenuhi } \\
\text { kriteria EEC } 2\end{array}$} & \multicolumn{2}{|c|}{$\begin{array}{c}\text { Memenuhi } \\
\text { kriteria EEC } 2\end{array}$} & \multicolumn{2}{|c|}{$\begin{array}{c}\text { Memenuhi } \\
\text { kriteria EEC } 2\end{array}$} & \multicolumn{2}{|c|}{$\begin{array}{c}\text { Memenuhi } \\
\text { kriteria EEC } 2\end{array}$} \\
\hline $\begin{array}{l}\text { Perolehan } \\
\text { Poin }\end{array}$ & \multicolumn{2}{|c|}{2 Poin } & \multicolumn{2}{|c|}{2 Poin } & \multicolumn{2}{|c|}{2 Poin } & \multicolumn{2}{|c|}{2 Poin } \\
\hline
\end{tabular}

Gedung 45 baseline telah memenuhi kriteria dalam hal iluminasi pencahayaan alami pada bangunan. Sehingga upaya penurunan nilai OTTV tidak boleh mengganggu iluminasi pencahayaan alami yang masuk ke dalam bangunan. Tiga skenario yang digunakan untuk menurunkan nilai OTTV diupayakan untuk tidak mengganggu kriteria mengenai iluminasi pencahayaan alami pada Gedung 45, sehingga kriteria mengenai pencahayaan alami tetap terpenuhi.

\section{PERBANDINGAN PENURUNAN NILAI OTTV SETIAP VARIABEL}

Perbandingan antara ketiga variabel optimalisasi dapat dilihat pada tabel berikut.

Tabel 0.13. Perbandingan Nilai OTTV berdasarkan Optimalisasi Variabel Koefisien Peneduh, Material Bukaan, dan WWR

\begin{tabular}{|c|c|c|c|c|c|c|c|c|}
\hline & \multicolumn{3}{|c|}{ Baseline } & $\begin{array}{l}\text { Variabel } \\
\text { Koefisien } \\
\text { Peneduh }\end{array}$ & \multicolumn{2}{|c|}{$\begin{array}{c}\text { Variabel } \\
\text { Material } \\
\text { Bukaan }\end{array}$} & \multicolumn{2}{|c|}{ Variabel WWR } \\
\hline & Uf & WWR & $\begin{array}{c}\% \\
\text { area }> \\
300 \\
\text { lux }\end{array}$ & $\begin{array}{c}\text { Tidak } \\
\text { Efektif }\end{array}$ & Uf & $\begin{array}{c}\% \text { area } \\
>300 \\
\text { lux }\end{array}$ & WWR & $\begin{array}{c}\% \text { area }> \\
300 \text { lux }\end{array}$ \\
\hline Lantai 1 & 5.28 & $45 \%$ & $51 \%$ & & 1.8 & $51 \%$ & $27 \%$ & $39.2 \%$ \\
\hline Lantai 1A & 5.28 & $61 \%$ & $37 \%$ & & 1.8 & $37 \%$ & $48 \%$ & $30.3 \%$ \\
\hline Nilai OTTV & \multicolumn{3}{|c|}{$39.68 \mathrm{~W} / \mathrm{m}^{2}$} & - & \multicolumn{2}{|c|}{$29.78 \mathrm{~W} / \mathrm{m}^{2}$} & \multicolumn{2}{|c|}{$28.62 \mathrm{~W} / \mathrm{m}^{2}$} \\
\hline Biaya (Rp) & \multicolumn{3}{|c|}{-} & - & \multicolumn{2}{|c|}{388.319 .810} & \multicolumn{2}{|c|}{$43,197,040$} \\
\hline
\end{tabular}

Optimalisasi berdasarkan variabel WWR dan material merupakan variabel yang paling efektif menurunkan nilai OTTV. Optimalisasi berdasarkan variabel material bukaan tidak memberi dampak terhadap iluminasi cahaya alami dan tidak merubah fasad, tetapi membutuhkan biaya yang besar. Sedangkan optimalisasi berdasarkan variabel WWR tidak membutuhkan biaya yang besar tetapi memiliki konsekuensi terhadap perubahan fasad dan iluminasi cahaya alami yang masuk ke dalam bangunan.

\section{KESIMPULAN DAN SARAN}

\subsection{KESIMPULAN}

Berdasarkan proses analisa, terdapat dua kategori yang dapat diterapkan untuk menurunkan nilai OTTV tanpa mengganggu kriteria penilaian bangunan hijau yang lain: 
a. Melakukan optimalisasi berdasarkan material bangunan; optimalisasi material bangunan memiliki kelebihan, diantaranya tidak mengubah fasad bangunan dan dapat memasukan iluminasi cahaya alami yang sama dengan sebelum proses penurunan nilai OTTV. Optimalisasi berdasarkan material memiliki kelemahan yaitu biaya yang digunakan lebih besar dibandingkan dengan jenis optimalisasi yang lain dan menimbulkan banyak material sisa karena dilakukan penggantian material yang sudah terpasang.

b. Melakukan optimalisasi berdasarkan nilai WWR bangunan; optimalisasi berdasarkan nilai WWR memiliki kelebihan dari segi biaya karena biaya yang digunakan lebih murah. Penutupan dilakukan tanpa membuang material yang sudah ada, material yang sudah ada bekerja sebagai lapisan insulasi peredam panas sehingga material tidak terbuang percuma. Kelemahan dari optimalisasi berdasarkan nilai WWR yaitu iluminasi cahaya alami pada bangunan cenderung akan menurun karena ada bagian bukaan yang ditutup dan membutuhkan kreativitas untuk menutup bukaan agar tidak merusak fasad bangunan.

Berdasarkan dua kategori tersebut, dapat disimpulkan 4 buah skenario/alternatif yang dapat dilakukan untuk menurunkan nilai OTTV diantaranya:

a. Mengganti seluruh material bukaan dengan kaca low-E yang memiliki nilai Uf minimum sebesar $1.97 \mathrm{~W} / \mathrm{m} 2 \mathrm{~K}$ agar tidak mengubah fasad Gedung 45 dan tidak merubah iluminasi cahaya alami pada bangunan.

b. Memperkecil nilai WWR pada lantai 1 orientasi barat dan utara bangunan. Nilai WWR pada orientasi barat lantai 1 bangunan diperkecil menjadi 18\%, sedangkan orientasi utara lantai 1 bangunan diperkecil menjadi 39\%. Nilai OTTV yang diperoleh yaitu 34.53, dengan persentasi luas lantai yang memiliki luminasi pencahayaan alami lebih dari 300 lux sebesar $40.6 \%$ pada lantai 1 dan $37 \%$ pada lantai $1 \mathrm{~A}$.

c. Memperkecil nilai WWR pada lantai 1 seluruh orientasi bangunan. Nilai WWR pada lantai 1 diperkecil menjadi $26 \%$ pada orientasi timur, $37 \%$ pada orientasi selatan, $15 \%$ pada orientasi barat, dan $32 \%$ pada orientasi utara. Nilai OTTV yang diperoleh yaitu 32.18 $\mathrm{W} / \mathrm{m} 2$, dengan persentasi luas lantai yang memiliki luminasi pencahayaan alami lebih dari 300 lux sebesar $39.2 \%$ pada lantai 1 dan $37 \%$ pada lantai $1 \mathrm{~A}$.

d. Memperkecil nilai WWR pada lantai 1 dan lantai 1A seluruh orientasi bangunan. Nilai WWR pada lantai 1 diperkecil menjadi $26 \%$ pada orientasi timur, $37 \%$ pada orientasi selatan, $15 \%$ pada orientasi barat, dan $32 \%$ pada orientasi utara. Nilai WWR pada lantai 1A diperkecil menjadi $34 \%$ pada orientasi timur, 52\% pada orientasi selatan, $56 \%$ pada orientasi barat, dan $54 \%$ pada orientasi utara. Nilai OTTV yang diperoleh yaitu 28.62 $\mathrm{W} / \mathrm{m} 2$, dengan persentasi luas lantai yang memiliki luminasi pencahayaan alami lebih dari 300 lux sebesar $39.2 \%$ pada lantai 1 dan $30.3 \%$ pada lantai $1 \mathrm{~A}$.

\subsection{SARAN}

Setelah melakukan proses penelitian dan diperoleh hasil penelitian yang telah disimpulkan dalam sub-bab kesimpulan penelitian, maka dapat dirumuskan saran penelitian yang berguna bagi beberapa pihak yaitu sebagai berikut:

a. Saran untuk pihak yayasan/panitia pembangunan PPAG, nilai OTTV Gedung 45 dapat diturunkan dengan mengubah material bukaan atau mengubah konfigurasi WWR. Penerapan konfigurasi tersebut dapat meningkatkan nilai Gedung 45 sebesar 3 hingga 5 poin tanpa mengganggu kriteria penilaian yang lain.

b. Saran yang berguna untuk dunia arsitektur:

- Pengurangan nilai OTTV dapat dilakukan dengan mengurangi nilai WWR, mengubah material bangunan, dan memberi elemen peneduh pada bangunan.

- Aspek WWR merupakan aspek yang paling efektif berdasarkan kriteria biaya, usaha, dan efektifitas. Aspek material bangunan dapat digunakan apabila fasad bangunan tidak 
ingin terganggu dan tidak mengurangi iluminasi pencahayaan alami pada bangunan. Aspek peneduh pada bangunan merupakan aspek yang kurang efektif karena efisiensi peneduh akan semakin berkurang seiring dengan bertambahnya panjang peneduh.

- Untuk mengurangi nilai WWR pada bangunan dapat digunakan langkah-langkah sebagai berikut:

o Menganalisis ruangan dengan fungsi yang tidak membutuhkan pencahayaan alami (ruang pameran dan area servis). Ruangan dengan fungsi yang tidak membutuhkan pencahayaan alami tersebut dapat ditutup bukaannya sehingga dapat menurunkan nilai WWR pada bangunan

o Apabila langkah sebelumnya sudah dilakukan, maka dapat dilakukan penutupan bukaan mulai dari bagian bawah bukaan. Penutupan bagian bawah bukaan bertujuan agar pemandangan keluar gedung dapat tetap tercapai (yang juga merupakan salah satu syarat greenship). Ukuran penutupan bukaan harus sesuai dengan modul material yang ada di pasar (kelipatan 30,60, $120 \mathrm{~cm}$ )

- Perancangan bangunan yang mempertimbangkan aspek lingkungan merupakan suatu hal yang wajib dilakukan karena memperbaiki nilai OTTV akan mengeluarkan biaya yang lebih banyak dibandingkan dengan merancang bangunan dengan nilai OTTV yang telah memenuhi syarat sejak awal.

c. Saran yang berguna untuk penelitian yang akan dilakukan di masa yang akan datang:

- Metode penelitian yang digunakan ini dapat pula digunakan sebagai dasar untuk mengurangi nilai OTTV pada bangunan lain. - Diperlukan penelitian lebih lanjut dengan variabel penelitian berupa gabungan dari variabel perhitungan OTTV. Sehingga nilai OTTV dapat menjadi semakin optimal

\section{DAFTAR PUSAKA}

Admin web. (2013). Perbandingan Hebel dan Bata Merah. Diakses tanggal 23 Februari 2017, dari http://www.hebelpanel.com/2013/02/perbandingan-bata-merah-dan-bata-ringan.html

AGC Group. Planibel Glass [Brosur]. Diakses tanggal 27 April 2017, dari http://asahimas.arwuda.com/id/produk/kaca-lembaran/brosur/

Amaruloh, Dede. (2015). Menghitung Nilai OTTV Bangunan Gedung. Diakses tanggal 18 Februari 2017, dari http://dedeamaruloh.blogspot.com/2015/12/menghitung-nilai-ottv-bangunangedung.html

GBCI. (2013). GREENSHIP Panduan Teknis Perangkat Penilaian Bangunan Hijau Untuk Bangunan Baru versi 1.2. Jakarta: Green Building Council Indonesia

INDONESIA. Pemerintah Kotamadya Bandung. 2016. Peraturan Walikota Bandung no, 1023 tahun 2016 tanggal 26 Agustus 2016 tentang Bangunan Gedung Hijau. Bandung.

INDONESIA. Badan Standardisasi Nasional. SNI 03-6389-2011 tentang Konservasi Energi Selubung Bangunan pada Bangunan Gedung. Jakarta.

INDONESIA. Badan Standardisasi Nasional. SNI 03-2396-2001 Tata Cara Perancangan Sistem Pencahayaan Alami pada Bangunan Gedung. Jakarta.

N.D. (2013). Pengertian Konduksi, Konveksi, dan Radiasi. Diakses tanggal 15 Maret 2017, dari. www.pengertianahli.com/2013/11/pengertian-konduksi-konveksi-radiasi.html

PPG Industries. (n.d.). Laminated Glass, Thermal and Optical Properties. Diakses tanggal 24 Maret 2017, dari: http:// buyat.ppg.com / glasstechlib / 129_TD-128 \%20 Laminated \%20Glass\%20$\% 20$ Thermal\%20and\%20Optical\%20Properties.pdf 